\title{
Mukhabarah: Profit Loss Sharing Financing Scheme in Agricultural Land Management (Study in Tumpang District)
}

\author{
Santi Merlinda \\ Universitas Negeri Malang \\ e-mail: santi.merlinda.fe@um.ac.id \\ Vidya Purnamasari \\ Universitas Negeri Malang \\ Ahmad Fawaiq Suwanan \\ Universitas Negeri Malang \\ Syahrul Munir \\ Universitas Negeri Malang
}

\begin{abstract}
Schemes in the management of agricultural land are very diverse, ranging from selfmanagement and cooperation through mukhabarah, muzara'ah contracts to rental systems. This paper aims to precisely determine the scheme of cooperation in the management of agricultural land in Tumpang District. The most frequently used of the several land management cooperation schemes is mukhabarah, which benefits both landowners and smallholders. The approach used is qualitative, with a case study method. The population in this study were all agricultural landowners in Tumpang District, and the sample used was landowners who used the mukhabarah scheme. Then, the instrument in this study was in-depth interviews conducted on smallholders and landowners. This study indicates that the mukhabarah scheme provides higher income to landowners compared to the rental system. Meanwhile, from the side of smallholders, the mukhabarah scheme provides and opens job opportunities and increases income from land management. Another trivial thing but becomes an important point is that landowners and sharecroppers can still share agricultural products with residents/neighbors through this scheme.
\end{abstract}

Keywords: mukhabarah, agriculture land, Tumpang, financing scheme 


\begin{abstract}
Abstrak
Skema dalam pengelolaan lahan pertanian sangat beragam, mulai dari pengelolaan mandiri, maupun kerjasama melalui akad mukhabarah, muzara'ah sampai dengan sistem sewa. Tujuan dari tulisan ini adalah mengetahui secara spesifik skema kerjasama dalam pengelolaan lahan pertanian di Kecamatan Tumpang. Dari beberapa skema kerjasama pengelolaan lahan, yang paling sering digunakan adalah mukhabarah, yang menguntungkan pihak pemilik lahan maupun petani penggarap. Pendekatan yang digunakan adalah kualitatif, dengan metode studi kasus. Populasi dalam penelitian ini adalah seluru pemilik lahan pertanian di Kecamatan Tumpang, dan sample yang digunakan adalah pemilik lahan yang menggunakan skema mukhabarah. Kemudian, instrumen dalam penelitian ini adalah wawancara mendalam yang dilakukan pada petani penggarap dan pemilik lahan. Hasil dari penelitian ini menunjukkan bahwa skema mukhabarah memberikan pendapatan yang lebih tinggi pada pemilik lahan dibandingkan dengan skema sewa. Sedangkan dari sisi petani penggarap, skema mukhabarah memberikan dan membuka kesempatan kerja serta peningkatan pendapatan atas pengelolaan lahan.. Hal lain yang sepele namun menjadi poin penting adalah, melalui skema ini pemilik lahan maupun petani penggarap masih bisa berbagi hasil pertanian dengan penduduk/ tetangga sekitar.
\end{abstract}

Kata kunci: Mukhabarah, Lahan Pertanian, Tumpang, Skema Pembiayaan

\title{
INTRODUCTION
}

Agriculture is a strategic and crucial sector in a country. Indonesia is one of the agrarian countries, with the agricultural industry which continues to grow positively by 1.75 percent in addition to the Financial Services and Insurance sectors; and the Information and Communications sector in 2020, compared to the previous year (BPS RI, 2021). One of the areas designated as a national food barn is East Java (Ministry of Agriculture of the Republic of Indonesia, 2020). One of the areas with an agricultural base in East Java is Malang Regency. One of the priority areas for agricultural development in Malang Regency that focuses on food crops is Tumpang District (Cipta et al., 2017). Tumpang sub-district is the only area with a level 1 hierarchy, which has sufficient agricultural facilities for the size of agricultural land, with the leading commodities of Rice, Corn, Sweet Potatoes and supporting entities of Corn, Sweet Potato, Potato, Cabbage, Kangkung, Spinach (Cipta et al. al., 2017).

There are several models in the management of agricultural land in Tumpang District, including independent, semi-independent, and cooperation models. Independent control means that the owner carries out all agricultural land management activities. Then, semi-independent management implies that almost all activities are carried out by the landowner independently. Only a few activities use the services of others, such as tandur (planting seeds), matun (cleaning weeds, or other activities. Through cooperation, land management systems can include musaqah, muzara'ah, and mukhabarah (Shidiqie, 2017). Land management through collaboration is carried out between individuals and banks or individuals with individuals. Financing schemes carried out by banks for the agricultural sector include: (i) Murabahah, (ii) Salam, (iii) Istisna, (iv) Ijarah, (v) Musyarakah, and (vi) Mudharabah (Nasution, 2016).However, several components of the agricultural sector are less attractive to banks in the 
financing, including the food crops subsector. Plantation sub-sector, livestock subsector, and fishery sub-sector due to the high risk of falling prices. Prices in the agricultural sector cause low funding commitments from financial institutions due to potential problems such as increasing farmer debt and bad loans (Yazid et al., 2021). One solution to the problem of low financing is optimizing agricultural productivity and management through several types of cooperation, either through musyarakah, partnerships, or other forms of collaboration (Saragih, 2017).

Strong arguments in Islamic financing for the agricultural sector are: (i) The characteristics of Islamic financing are by the characteristics of the agricultural sector, due to the distribution of profits and losses: (ii) Islamic financing schemes have been widely practiced by Indonesian farmers who are almost the same as maro or mertelu or the concept of mudharabah; (iii) The breadth of the agricultural sector business scope; (iv) Diverse Islamic financing products; (v) farmers in rural areas generally still respect religious rules to be applied in their daily lives; (vi) Commitment of Islamic banks for Small and Medium Enterprises; and (vii) Business in the agricultural sector is a real business, which is by the principles of Islamic banking (Saragih, 2017).

Most of the cooperation contracts in the management of agricultural land in Tumpang District are mukhabarah. This management model collaborates between landowners and cultivators to manage the ground, where the capital/seeds come from the cultivators (Shidiqie, 2017). The production-sharing agricultural management model in Tumpang District, known as maro or mertelu, is adapted to the type of plant. Several areas have established a profit-sharing system in agricultural management, for example, Praya Timur District, Central Lombok Regency, known as nyakap (Mutallib, 2015), Karisedenan Madiun (Arief and Susilo, 2019), Gamping District, Sleman Yogyakarta (Priyadi and Shidiqie, 2015), Waung Village, Baron Subdistrict, Nganjuk Regency (Hermawan, 2012), Temu Village, Kanor Bojonegoro Subdistrict (Primada and Zaki, 2015), Corn Village, Kesesi Subdistrict, Pekalongan Regency (Wahyuningsih, 2011), Sidrap South Sulawesi Province (Wahyu, 2019), Semadam District, Southeast Aceh Regency (Furqan, 2016) and Gorontalo, known as mogarapu pangimba lo tau or mo balandangia (Darwis, 2016). According to the ratio agreed at the beginning, each region has a different profit-sharing percentage, depending on the area, customs, and crop type.

The mukhabarah scheme is widely used by landowners, compared to ijarah or other management methods. In Semadam, Aceh Tenggara, most people prefer the mukhabarah scheme in agricultural management than muzara'ah or other systems due to the narrower land area, changing cropping patterns, more limited jobs opportunities, honesty (inappropriate contracts), and economic needs (Furqan, 2016). Another reason for choosing a mukhabarah scheme is that landowners and cultivators can enjoy the results together, increase benefits, and benefit equally (Mutallib, 2015). The benefits received in addition to profits in the form of money are also benefits of brotherhood because of the mutual help interaction between landowners and sharecroppers (Wahyu, 2019 and Haryati, 2019). In addition, several other reasons for the need for this collaboration are: (i) smallholders do not own land; (ii) the land of smallholders is not too large; (iii) landowners are unable to cultivate themselves; and (iv) landowners who live far from arable land (Darwis, 2016). Owners benefit because the land used as an investment medium can still be productive (not unemployed) even though they do not have expertise in agriculture. On the other hand, sharecroppers who have knowledge but do not have the resources in the form of land also benefit from having workable land.

Based on previous research, the management of agricultural land through the 
mukhabarah scheme benefits managers who do not own land or landowners who live far from agricultural land, do not have the expertise and do not have sufficient capital. However, not all people understand the scheme and implementation of mukhabarah in agricultural land management, which has various benefits. Therefore, the purpose of this study is to find out how to optimize the mukhabarah scheme in the control of agricultural land in Tumpang District, Malang Regency, which has implemented the mukhabarah scheme.

\section{LITERATURE REVIEW}

\section{Mukhabarah Concepts and Laws}

Mukhabarah is the management of land owned by other people in exchange for the results (half, one-third, or a quarter according to the agreement). The seeds and management costs come from the cultivators (Furqan, 2016; Abdullah, 2017; Wahyu, 2019). Muzara'ah is also named as al-mukhabarah and muhaqalah (Zainuddin and Suhamdani, 2016). Mukhabarah is very close and almost the same as muzara'ah. It's just that the difference is the origin of the seed, where mukhabarah is the seed from the cultivator; on the contrary, the muzara'ah is the seed that comes from the farmer (Wahyu, 2019 and Wahyuningrum et al., 2020). The meaning of mukhabarah also adopts the thoughts of the Shafi'iyah scholars as follows:

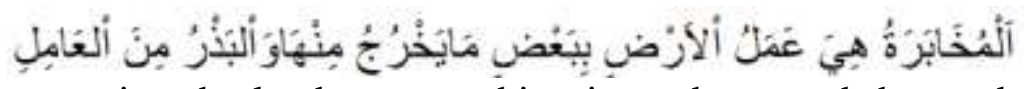

Meaning: "Mukhabarah is managing the land on something it produces and the seeds come from the manager" (Syafe'i, 2001).

The concept of mukhabarah is similar to mudharabah, but mukhabarah is more specific and specialized in agriculture. Furthermore, Syafe'i (2001) explained that in the idea of law, Imam Hanafi and Jafar considered muzara'ah as fasid, as did Imam Shafi'i. However, some Syafi'iyah scholars admit and use musaqah, but they do not allow mukhabarah because it has no basis. On the other hand, Abu Yusuf and Muhammad (friends of Imam Abu Hanifah), Imam Malik, Ahmad, and Abu Dawud Azh-Zahari argued that muzara'ah was permissible. The basis of the law is permitted a hadith narrated by the congregation from Ibn Umar that the Prophet Muhammad SAW transaction with Khaibar experts, where the percentage of acquisition is half of the results of plants and fruits. In addition, muzara'ah can be categorized as property and work cooperatively to establish a symbiotic mutualism between the cultivator and the landowner. According to the consensus of the scholars, mukhabarah includes hereditary sharia (Syariah Mutawaritsah), where the salaf scholars and Khalaf scholars have practiced the scheme (Adam, 2017). Furthermore, the mukhabarah scheme in agricultural management is legally permissible (Wahyuningrum et al., 2020).

\section{Principle and Term of Mukhabarah}

The principle of muzara'ah/mukhabarah, according to Hanafiyah scholars, is ijab qabul, which shows agreement from both parties, while according to Hanabilah scholars, qabul is not necessarily needed in lafadz/remark (Syafe'i, 2001). Furthermore, the conditions in muzara'ah/mukhabarah according to Abu Yusuf and Muhammad (a friend of Imam Abu Hanifah), the terms of mukhabarah are related to: 
1. Aqid (the person who holds the contract): mumayyiz (but not recommended for puberty), Abu Hanifah requires that he is not an apostate, but Hanafiyah scholars do not oblige.

2. Plants: differences between scholars, but most consider it better left to workers.

3. Cultivated land: it is possible to cultivate (can produce), it is clear, there is an ijab qabul.

4. The plants produced are apparent when the contract takes place, then the percentage distribution is based on the entire harvest between the two parties, namely the cultivator and the landowner.

5. The purpose of the contract: must be based on the meaning of syara' (religion) to help each other.

6. Requirements for farming tools: it is allowed to use traditional or modern tools.

7. Time of planting: must be determined; otherwise, it is considered invalid.

According to Malikiyah scholars, the conditions for muzara'ah/mukhabarah include:

1. Both parties entering into the contract must submit seeds.

2. The results obtained must be equalized between the landowner and the cultivator.

3. The sources must come from both parties who enter into the contract.

Then, according to the scholars of Syafi'iyah and Hanbilah, there is no requirement for equality between income in a muzara'ah/mukhabarah contract related to musaqah.

Furthermore, the muza'raah/mukhabarah contract expires; if one of the parties making the contract dies, an excuse causes the muzara'ah/mukhabarah to be canceled. For example, the arable land had to be sold, or the cultivator could not manage the ground due to illness and other reasons (Syafe'i, 2001).

\section{Implementation of the Mukhabarah Scheme}

Implementing a profit-sharing scheme in the agricultural sector is also carried out in Malaysia through equity participation by Islamic banks. Banks provide producers of production inputs (seeds, fertilizers, and agricultural production machines) and agricultural product processing businesses to their distribution (Budiasa, 2020). The mukhabarah scheme can increase the benefits for both sharecroppers and landowners in East Praya District (Mutallib, 2015). The form of help felt by cultivators and landowners in meeting material needs, children's education costs, paying zakat as a religious obligation, alms, and having food supplies for a certain period. In general, implementing profit sharing uses the $1 / 3$ method for the cost of management, landowners, and cultivators. However, if the contract is not clarified initially, then the landowner determines the distribution. Then, in Nusa Indah Hamlet, Margomulyo Village, Tomoni Timur District, East Luwu Regency, the distribution is $3 / 4$ (three quarters) for agricultural land managers and $1 / 4$ (quarter) for landowners (Zainuddin and Suhamdani, 2016). The profit-sharing is because the landowner bears all the operational costs.

In addition to the agricultural sector, the concept of mukhabarah is also found in the cattle breeding sector in Bone Regency (Asnawi et al., 2018). The relationship and the idea of a profit-sharing agreement between farmers and livestock owners are based on trust. Profit-sharing is carried out at the end of the transaction (after harvesting), where the livestock owners submit their livestock, while the farmers provide land, cages, feed, water, and labor. However, the financing scheme for cattle farming in Bone Regency is integrated between the local government, banks, livestock owners, farmer groups, and breeders. 


\section{METHOD}

The approach used in this research is phenomenology, with a case study method, which is an in-depth study of only one group. Approach with a case study, focusing on the problem of the study, without any intervention in other cases (Bungin, 2020). The sampling method in this research is purposive sampling. The research subject was the owner of agricultural land in the Tumpang sub-district with the sharecroppers who collaborated through a mukhabarah contract. Data collection techniques in this study were in-depth interviews and observation. Next, the data analysis procedure is through triangulation.

\section{RESULT AND DISCUSSION}

Implementing the mukhabarah scheme on agricultural land in Tumpang District is almost the same as the basic concept. Before implementing the contract, landowners and managers (cultivators) conduct discussions regarding the implementation system and profit-sharing patterns. The implementation system includes contract selection, plant type selection decisions. In general, the cultivator determines the type of plant. Then, the cultivator proposes to the landowner through discussion based on market opportunities and the climate at planting. However, landowners usually leave it to the cultivators for the plants and seeds because they better understand the market situation and crop resilience.

The profit-sharing pattern in the mukhabarah contract for vegetable crops in Tumpang District generally adheres to the "mertelu" or one-third division system. Mertelu pattern means that the harvest is divided into three, namely for (i) operational costs and seeds; (ii) smallholders; (iii) and landowners. The yield before being distributed to the garden owners and sharecroppers will minus operating costs. In the process of land cultivation, farmers usually also need the help of other workers. The management process involves farmers and land managers, and farm laborers who assist in the land management process. Service assistance provided by farm laborers includes preparing the land, clearing grass, or other management processes. In addition to farm laborers, managers usually also cooperate with cultivated fields in preparing the ground.

In addition to workers, land managers usually also provide seeds, ensure water availability from the land irrigation process, and other costs such as fertilizers and pesticides as part of operational costs. Then, in addition to operating expenses, before profit sharing, there is usually some share of agricultural produce given to the surrounding community, including if there are vegetables/agricultural products of poor quality. In addition, the manager or landowner consumes a small portion of the harvest. 


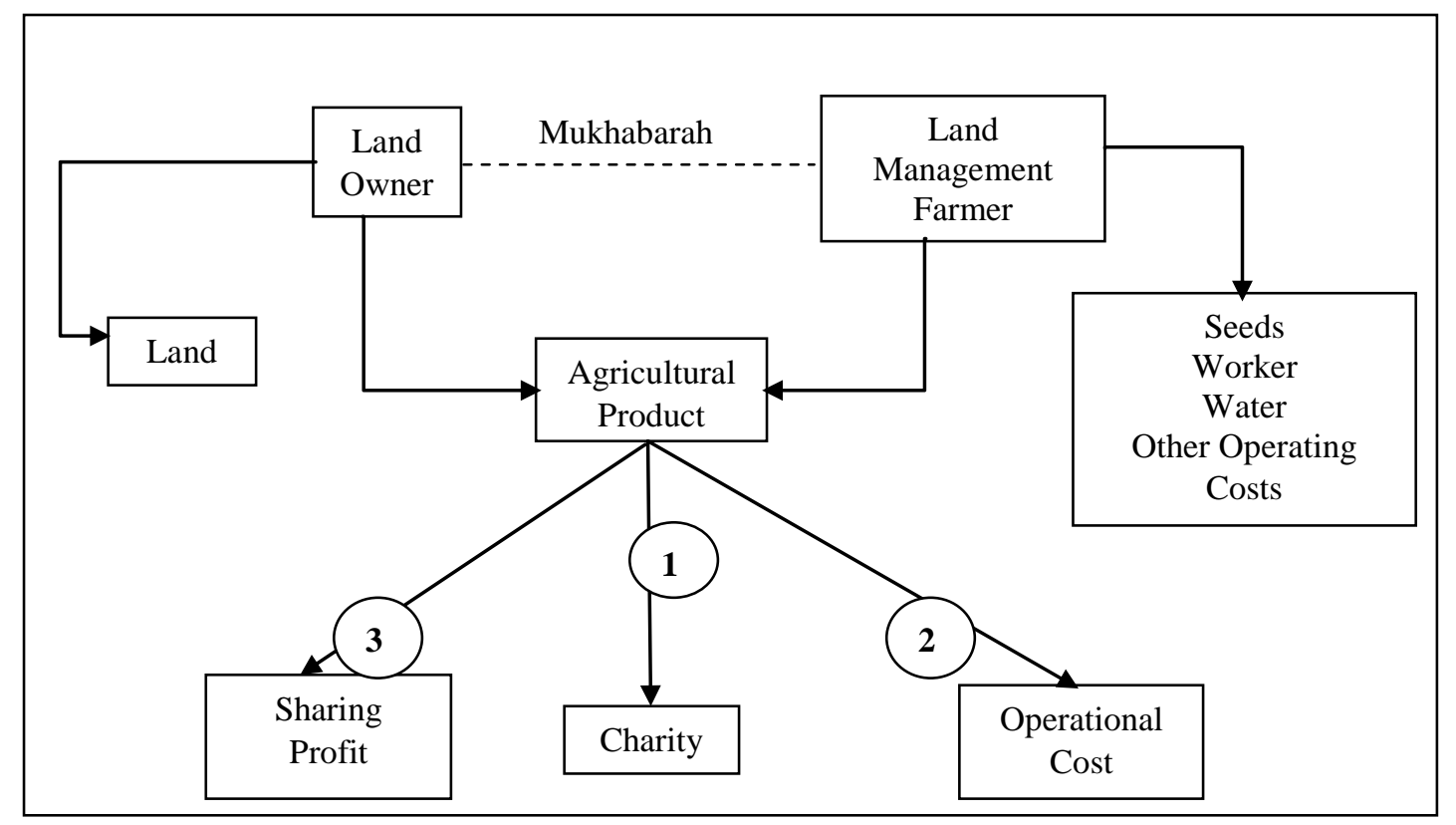

Figure 1. Mukhabarah Model in Tumpang District

Agricultural land management schemes with mukhabarah contracts are an alternative for landowners who do not have skills in agriculture. This scheme is more profitable than the lease/ijarah contract. Because when using a lease contract, the income received on agricultural land will remain every year. However, when using a profit-sharing agreement with a mukhabarah scheme, the average land owner's income is higher than the ijarah. This significant income does not mean that it is always large at every harvest, it will still fluctuate, and sometimes the results received are extensive and vice versa. Land rent/ijarah on agricultural land, especially for rice fields, in Tumpang District per hectare is around 16 million per ha.

Meanwhile, crop yields will be greater through land management cooperation, although it fluctuates. On average, the income received in the mukhabarah scheme is about three times compared to ijarah. The concept of profit-sharing also improves the welfare of cultivators and landowners in terms of material (wealth), as well as farmers in Maduran Village (Hidayati and Oktafia, 2020) and Gorontalo Regency (Darwis, 2016). In addition to increasing wealth, several other indicators in maslahah also increased, including (i) Religion (Ad-Dien) in the form of increasing Jariyah practices, such as infaq, alms, and zakat; (ii) Life (An-Nafs) in the form of fulfilling health needs such as for purchasing medicine (when sick) and payment for BPJS health insurance); (iii) Intellect (Al-Aql) in the form of increasing the understanding of agricultural cooperation actors regarding land management and crop quality; and (iv) Descendants (An-Nasl) in the form of fulfilling children's education costs.

In addition, managers usually plant other crops on the edge of the fields and the main crop in managing agricultural land. The plant is generally in the form of cassava or different types of vines. In addition to managers, landowners, surrounding communities, or communities in need can enjoy or consume the harvest. The crops on the edge of the fields have a dual function. Besides being given to those in need, it also functions as a fence/primary plant protector. In addition to performing as a fence, the surrounding community can freely take the hedge plant results as a form of sadaqah for the harvest. 
Thus, the share of profit sharing from agricultural land management calculates the difference between profits minus operational costs after the local community takes a small portion of agricultural produce.

The profit-sharing scheme uses a share of mertelu or one-third for vegetable commodities, where each claim is for operational costs, farmers, and landowners. Religiously, the agreement is allowed if both parties agree. The distribution of harvests in the Tumpang sub-district also follows Presidential Instruction No. 13/1980, concerning Guidelines for the Implementation of Law No. 2/1960, regarding the Production Sharing Agreement as regulated in Article 4 paragraph (1). The presidential instruction governs the amount of distribution. The distribution system uses the maro or half scheme (half each for farmers and landowners). Then, suppose the items are secondary crops in paddy fields and rice grown in dry areas. In that case, the distribution system is $2 / 3$ (two-thirds) for sharecroppers and $1 / 3$ (one-third) for landowners (Inpres of the Republic of Indonesia Number 13 of 1980 concerning Guidelines for the Implementation of Law Number 2 of 1960 regarding Production Sharing Agreements). The percentage of distribution is the same as the Waung Village system, Baron District, Nganjuk Regency (for Palawija commodities) (Hermawan, 2012). If there is a loss, the bearer is the sharecropper, similar to the concept in Maduran Village, Lamongan, East Java (Hidayati and Oktafia, 2020).

The uniqueness of the mukhabarah scheme is the establishment of a closer kinship relationship between landowners and sharecroppers. This close relationship is due to the intensity of discussions about agricultural land. This discussion will provide new knowledge for landowners about crops, care, and land management. In other words, social capital (network) between sharecroppers and landowners will increase.

On the other hand, the drawback of this scheme is the lack of transparency in the management of agricultural land. Cultivators only provide profits to landowners without reports in details of operational costs and sales results. In addition, the form of the agreement is also still carried out verbally, without any written evidence, with a period of the contract that is not clearly defined (Shidiqie, 2017; and Hidayati and Oktafia, 2020). Then, in the Tumpang sub-district, the risk of crop failure is still borne by smallholders, the same as most conditions in Maduran Village (Hidayati and Oktafia, 2020) and in Gamping District, Yogyakarta (Priyadi and Shidiqie, 2015).

One of the efforts to anticipate the risk of loss is to optimize agricultural management. Optimization in the direction of farming products is through strengthening farmer institutions, which facilitates farmers in running a farming business from upstream or early stages of production to downstream or distribution of business results as in Central Java (Darwanto et al., 2019). The purpose of managing post-harvest agricultural products is to increase the added value of the farming sector, especially in post-harvest management. In addition, the explanation in the mukhabarah contract would be better if it was written in an agreement document. The purpose of the description in this contract is to clarify the rights and obligations of land managers and landowners in managing agricultural land. Thus, this will minimize problems that may arise during land management. Besides that, each party will also know what to do when something terrible happens that cannot be predicted in advance. For example, a wind disaster that destroys crops, falling prices of agricultural commodities planted, and what must be done and borne by each party in the event of a loss, including the distribution of the percentage loss. 


\section{CONCLUSION}

The agricultural land management scheme in Tumpang Subdistrict with the mukhabarah system is still widely used by landowners, with a profit-sharing of $1 / 3$ for landowners and $2 / 3$ for smallholders (where smallholders also bear all operational costs, including plant seeds). The calculation of profit sharing after allocating a small portion of the harvest to the surrounding community as a form of gratitude to Allah SWT, in the form of alms. In addition, the operational costs of $1 / 3$ of the agricultural produce replace the costs of smallholders. Therefore, in general, the concept of sharing agricultural land in Tumpang District increases the benefit of landowners and sharecroppers, not only in terms of wealth but also in religion. However, the profit-sharing scheme in Tumpang District still has drawbacks in the form of lack of transparency of operational costs in land management and the several advantages stated. Therefore, it is crucial to agree in writing in the contract before the activity is carried out (Isnaeni, 2017). The agreement in the mukhabarah contract can be in the form of clarity when a loss occurs, the percentage of loss sharing, and the rights and obligations of each party, namely the land manager and the landowner. In addition, agriculture optimization can be done by increasing value added in the form of managing agricultural products into new highvalue products.

\section{REFERENCES}

Abdullah, M. R. (2017). "Bagi Hasil Tanah Pertanian (Muzara'ah) (Analisis Syariah Dan Hukum Nasional)”, Al-Amwal: Journal of Islamic Economic Law, Vol 2, No.2, pp 148-172. DOI: https://doi.org/10.24256/alw.v2i2.636

Asnawi, A., Amrawaty. A. A., and Nirwana.. (2018). "Mukhabarah as Sharia Financing Model in Beef Cattle Farm Entrepise", IOP Conference Series: Earth and Environmental Science, Vol. 119, No. 1, pp.1-6. DOI: https://doi.org/10.1088/1755-1315/119/1/012068

Badan Pusat Statistik Republik Indonesia. (2021). "Berita Resmi Statistik: Pertumbuhan Ekonomi Produk Domestik Regional Bruto", No.13/02/Th. XXIV, 5 Februari 2021, pp.33

Budiasa, I. W. (2020). "Green financing for supporting sustainable agriculture in indonesia", IOP Conference Series.Earth and Environmental Science, Vol.518, No.1, pp 1-11. DOI: https://doi.org/10.1088/1755-1315/518/1/012042

Bungin, Burhan. (2020). Post-Qualitative Social Research Methods: KuantitatifKualitatif-Mix Methods. Jakarta: Prenadamedia Group.

Cipta, S. W., Sitorus, S. R., \& Lubis, D. P. (2017). "Pengembangan komoditas unggulan di wilayah pengembangan tumpang, Kabupaten Malang”, Jurnal Kawistara, Vol.7, No.2, pp.121-133. DOI: https://doi.org/10.22146/kawistara.12495

Darwanto, Roessali, W., Woyanti, N., Salam, A. N., \& Santosa, P. B. (2019). "Sharia microfinance institutions financing model for strengthening agricultural sector", IOP Conference Series.Earth and Environmental Science, Vol 292, No. 1, pp 1-8. DOI: https://doi.org/10.1088/1755-1315/292/1/012016

Darwis, R. (2016). "Sistem Bagi Hasil Pertanian Pada Masyarakat Petani Penggarap Di Kabupaten Gorontalo Perspektif Hukum Ekonomi Islam”, Al-Mizan, Vol.12, No.1, pp.1-25. DOI: https://doi.org/10.30603/am.v12i1.122 
Furqan, M. (2016). "Pengaruh Prinsip Al-Muzara'ah dan Al-Mukhabarah terhadap Perjanjian Bagi Hasil Pertanian (Studi di Kecamatan Semadam Kabupaten Aceh Tenggara)". Premise Law Journal, 1, 14152, pp.1-17.

Haryati, D. (2019). "PENGARUH SISTEM BAGI HASIL TERHADAP KESEJAHTERAAN MASYARAKAT PETANI KEBUN KARET (STUDI KASUS DI DESA GALANG TINGGI KECAMATAN BANYUASIN III)". Ekonomica Sharia: Jurnal Pemikiran dan Pengembangan Ekonomi Syariah, Vol.4. No.2, pp.43-50. DOI: https://doi.org/10.36908/esha.v4i2.157

Hermawan, F. (2012). "Pelaksanaan Perjanjian Bagi Hasil Tanah Pertanian: Studi di Desa Waung Kecamatan Baron Kabupaten Nganjuk", Jurnal Ilmu Hukum Mizan, Vol.1, No.2, pp.91-99.

Hidayati, N., \& Oktafia, R. (2020). "IMPLEMENTASI AKAD BAGI HASIL PADA SEKTOR PERTANIAN DALAM PENINGKATAN KESEJAHTERAAN PETANI DI DESA MADURAN KECAMATAN MADURAN KABUPATEN LAMONGAN", Jurnal Ekonomi Syariah Teori dan Terapan, Vol 7, No.12, pp.2399-2418. DOI: http://dx.doi.org/10.20473/vol7iss202012pp2399-2418

INSTRUKSI PRESIDEN REPUBLIK INDONESIA NOMOR 13 TAHUN 1980 TENTANG PEDOMAN PELAKSANAAN UNDANG-UNDANG NOMOR 2 TAHUN 1960 TENTANG PERJANJIAN BAGI HASIL

Isnaeni, Moch. (2017). "IMPLIKASI PENUANGAN KONTRAK SEBAGAI BINGKAI BISNIS KE DALAM AKTA NOTARIIL", Jurnal Notariil, Vol. 2, No. 1 (2017), pp. 23-32. DOI: https://doi.org/10.22225/jn.2.1.149.23-32

Kementrian Pertanian Republik Indonesia, "Di Jatim, Pertanian Menjadi Sektor Paling Aman Dari Dampak Pandemi Corona”, https://www.pertanian.go.id/home/?show=news\&act=view\&id=4444

Mutallib, A. (2015). “Analisis sistem bagi hasil muzara'ah dan Mukhabarah pada usahatani padi dan implikasinya terhadap kesejahteraan keluarga petani penggarap dan pemilik lahan di Kecamatan Praya Timur", Jurnal Ilmiah Mandala Education, Vol.1, No.2, pp.245-257. DOI: http://dx.doi.org/10.36312/jime.v1i2.236

Nasution, Z. (2016). "Model pembiayaan syariah untuk sektor pertanian", IQTISHADIA: Jurnal Ekonomi dan Perbankan Syariah, Vol.3, No.2, pp.324-343.

Primada, B. S., \& Zaki, I. (2015). "Tinjauan Mekanisme Kontrak Pengelolaan Lahan Pertanian Berbasis Adat Istiadat Dalam Kajian Fiqh Muamalah (Desa Temu, Kecamatan Kanor, Kabupaten Bojonegoro)", Jurnal Ekonomi Syariah Teori dan Terapan, Vol.2, No.11, pp.954-969. DOI: http://dx.doi.org/10.20473/vol2iss201511pp954-969

Priyadi, U., \& Shidiqie, J. S. A. (2015). "Pelaksanaan Perjanjian Bagi Hasil Pertanian Lahan Sawah: Studi di Kecamatan Gamping, Kabupaten Sleman, Yogyakarta", Millah: Jurnal Studi Agama, Vol.15, No.1, pp.101-116. DOI: https://doi.org/10.20885/millah.vol15.iss1.art5

Rachmat Syafe'i. (2001). Fiqih Muamalah. Bandung: Pustaka Setia.

Saragih, F. H. (2017). Pembiayaan syariah sektor pertanian. Jurnal Agrica, Vol.10, No.2, pp.112-118. DOI: https://doi.org/10.31289/agrica.v10i2.1458

Shidiqie, J. S. A. (2017). "Mudharabah Hasil Pertanian Di Tinjau Dari Undang Undang Dan Hukum Islam", JESI (Jurnal Ekonomi Syariah Indonesia), Vol.7, No.1, pp.2231. DOI: http://dx.doi.org/10.21927/jesi.2017.7(1).22-31

Susilo, S. A. A., \& Susilo, A. (2019). "Faktor-Faktor yang Mempengaruhi Pemilihan Model Bagi Hasil Pada Sektor Pertanian di Wilayah Karesidenan Madiun”, Falah: 
Jurnal Ekonomi Syariah, Vol.4, No.2, pp.202-213. DOI: https://doi.org/10.22219/jes.v4i2.10091

Wahyu, A. R. M. (2019). "Sistem Penggarapan Lahan Pertanian Masyarakat: Perspektif Ekonomi Islam", Al-Azhar Journal of Islamic Economics, Vol.1, No.1, pp.1-15. DOI: https://doi.org/10.37146/ajie.v1i1.9

Wahyuningrum, A. L., \& Darwanto, D. (2020). "Penerapan Bagi Hasil Maro Perspektif Akad Mukhabarah", TAWAZUN: Journal of Sharia Economic Law, Vol.3, No.1, pp.45-62. DOI: http://dx.doi.org/10.21043/tawazun.v3i1.7544

Wahyuningsih, T. (2011). "Sistem Bagi Hasil Maro sebagai Upaya Mewujudkan Solidaritas Masyarakat", Komunitas: International Journal of Indonesian Society and Culture, Vol.3, No.2, pp.197-204. DOI: https://doi.org/10.15294/komunitas.v3i2.2316

Yazid, F., Kamello, T., Nasution, Y., \& Ikhsan, E. (2021). "Sharia based economics in support of Indonesia's sustainable agricultural sector", IOP Conference Series: Earth and Environmental Science, Vol. 782, No. 3, pp.1-6. https://doi.org/10.1088/1755-1315/782/3/032040

Zainuddin, S., \& Suhamdani, E. (2016). "MUZARA'AH DAN KESEJAHTERAAN MASYARAKAT LUWU TIMUR. MUAMALAH”, Jurnal Muamalah, Vol.6, No.1, pp 24-40. DOI: https://doi.org/10.24256/m.v6i1.701 